\title{
TXN Gene
}

National Cancer Institute

\section{Source}

National Cancer Institute. TXN Gene. NCI Thesaurus. Code C20816.

This gene plays a role in intercellular signaling, signal transduction and protection ag ainst cellular oxidative stress. 